\title{
FREQUENCY OF HUMAN TOXOCARIASIS IN A RURAL POPULATION FROM CAJAMARCA, PERU DETERMINED BY DOT-ELISA TEST
}

\author{
William H. ROLDÁN, Yrma A. ESPINOZA, Pedro E. HUAPAYA, Alina F. HUIZA, Carlos R. SEVILLA \& Susana JIMÉNEZ
}

\begin{abstract}
SUMMARY
The aim of this study was to estimate the frequency of human toxocariasis in Cauday district, Cajamarca, Peru, using a dot-ELISA test. From June to October 2005, a total of 256 adult subjects were studied. Blood samples were collected for serology by a dot-ELISA test and for hematological examination. Parasitological examination was also carried out in stool samples to check cross-reactions in the dot-ELISA. The frequency observed was $44.92 \%$, with a significant higher proportion of positivity in male subjects. From subjects with positive serology, $45.6 \%$ had respiratory symptoms, $40.44 \%$ abdominal pain, $32.35 \%$ hepatic symptoms, $14.7 \%$ cutaneous signs, $13.23 \%$ ocular manifestations, $43.38 \%$ eosinophilia, and all of these were statistically associated to serology. Among the population evaluated, $90.23 \%$ (231/256) were parasitized. From subjects with positive serology, $92.17 \%$ had at least one intestinal parasite and the most frequent were: Blastocystis hominis (68.38\%), Giardia lamblia (28.68\%), Hymenolepis nana (20.0\%), Ascaris lumbricoides (15.65\%), Entamoeba histolytica/E. dispar (13.24\%), Cyclospora cayetanensis (4.41\%), Cryptosporidium sp. (1.47\%), Enterobius vermicularis $(0.87 \%)$, Strongyloides stercoralis $(0.87 \%)$, Taenia sp. (0.87\%), and Trichuris trichiura (0.87\%). The rate of false positives in the dot-ELISA test was improved by serum absorption each with $A$. suum antigens, with a decrease of cross-reactions. In conclusion, human toxocariasis is highly frequent in this population and some risk factors like dog/cat ownership, presence of pets within house, and previous history of geophagia were observed in the present study.
\end{abstract}

KEYWORDS: Toxocariasis; Dot-ELISA; Frequency; Cross-reactions; Peru.

\section{INTRODUCTION}

Human toxocariasis is an accidental parasitic zoonosis due to human infection by larval stages of Toxocara canis and T. cati $^{11,24}$. The adult forms of these parasites reside in the digestive tract of their definitive host, the dogs and cats, respectively ${ }^{11,24}$. In humans, when Toxocara eggs containing infective larvae are accidentally ingested, the larvae hatch in the small intestine and migrate through somatic organs, preferably the liver and eyes, and leading to two different classical forms: visceral larva migrans (VLM) and ocular larva migrans (OLM) ${ }^{11,27}$. VLM is characterized by chronic weakness, abdominal pain, hepatic compromise, diverse signs of allergy and hypereosinophilia ${ }^{18,24,27}$. OLM occurs when larvae become trapped in the eyes, leading to uveitis and optic papillitis ${ }^{24,27,33}$. Furthermore, other symptomatic patterns can occur, such as covert toxocariasis, asthma, neurological, neurophysiological and occult infection ${ }^{24,34}$. Additional associated clinical characteristics are chronic allergy, bronchitis, urticaria, headache, behavioral disorders, vomiting, and abdominal pain ${ }^{11,24,27}$.

Human toxocariasis is primarily a zoonosis transmitted by soil with geophagia and poor hygiene habits increasing the risk of it. The clinical severity of this zoonosis depends on the total number of embryonated eggs ingested, as well as the ingestion frequency, and is more severe in children $^{27}$.

With the development of serological tests, seroprevalence studies also have been possible. The method of choice for serodiagnosis has been the ELISA test using Toxocara larvae excretion-secretion (TES) antigens ${ }^{19}$, which shows $78.3 \%$ to $100 \%$ of sensitivity and $90 \%$ to $92.3 \%$ of specificity ${ }^{4,19,31}$.

Toxocariasis prevalence is higher in tropical and developing countries and is generally associated with low socioeconomic level ${ }^{24}$. Different rates have been reported ranging from $1 \%$ in $\mathrm{Spain}^{28}$ to $86 \%$ in Santa Lucia $^{35} ; 3.6 \%$ to $24.7 \%$ in Brazil $^{2,9} ; 47.5 \%$ in Colombia ${ }^{1} ; 34.9 \%$ to $66.6 \%$ in Venezuela ${ }^{14,22}$, and $37.9 \%$ to $39 \%$ in Argentina ${ }^{3,30}$. In Peru, limited reports indicate frequencies of $7.8 \%$ to $20 \%$ in rural population and $40 \%$ in subjects with ocular suspicion ${ }^{12,13,21}$.

The aim of the present study was to determine the frequency of anti-Toxocara antibodies in a population from Cauday district, province of Cajabamba (Cajamarca, Peru) using a dot-ELISA test previously standardized $^{31}$, and its association with clinical manifestations and

Sección de Parasitología, Instituto de Medicina Tropical "Daniel A. Carrión”, Facultad de Medicina, Universidad Nacional Mayor de San Marcos, Calle José Santos Chocano 199, C.P. 10138, Callao, Perú.

Correspondence to: William H Roldán, Universidad Nacional Mayor de San Marcos, Instituto de Medicina Tropical "Daniel A. Carrión”, Sección de Parasitología,

Calle José Santos Chocano 199, C.P. 10138, Callao, Perú. Tel: +511 - 6197000 anexo 4404. E-mail: willyroldan23@hotmail.com 
ROLDÁN, W.H.; ESPINOZA, Y.A.; HUAPAYA, P.E.; HUIZA, A.F.; SEVILLA, C.R. \& JIMÉNEZ, S. - Frequency of human toxocariasis in a rural population from Cajamarca, Peru determined by DOT-ELISA test. Rev. Inst. Med. trop. S. Paulo, 51(2): 67-71, 2009.

some risk factors. Cross-reaction between serology and the presence of intestinal parasites were also evaluated.

\section{MATERIAL AND METHODS}

This study was carried out from June to October 2005, in Cauday district, province of Cajabamba, Cajamarca, Peru (Latitude $=7^{\circ} 34^{\prime} 60$ ' $\mathrm{S}$ and Longitude $=78^{\circ} 4^{\prime} 60^{\prime \prime} \mathrm{W}$ ). This town is located at $2714 \mathrm{~m}$ above sea level, at $124 \mathrm{~km}$ from South of Cajamarca city, to the left side of the river Condebamba. It has a mean temperature of $19{ }^{\circ} \mathrm{C}$ and an average relative humidity of $80 \%$. This place has an approximate population of 2000 inhabitants which are considered to be in the poorest socioeconomic condition, working on the agriculture. From this universe, 256 adult subjects between 17 to 58 years old were selected by random sampling.

An individual record was made and the following data were registered: anamnesis data, clinical signs and symptoms (pulmonary infiltrates, bronchospasms, bronchitis, hepatosplenomegaly, abdominal pain, leucocoria, strabismus, retinitis, visual loss, convulsions and other signs of central nervous system involvement, pruritus and chronic weakness); epidemiological data and risk factors, including age, sex, ownership of dogs or/and cats, their presence within the home, use of public places (central square and public parks), history of pica and/or geophagia. This research had the approval of the local ethical committee.

Blood samples were collected in vacutainer tubes with and without EDTA as anticoagulant, respectively. Serum was separated and stored at $-20{ }^{\circ} \mathrm{C}$ until use. For parasitological examination, stool samples were collected fresh or preserved in $10 \%$ saline-formalin solution at room temperature.

Total anti-Toxocara IgG antibodies were detected by dot-ELISA test, using TES antigens as described by ROLDÁN et al. ${ }^{31}$ with slight modifications. In order to improve the specificity of dot-ELISA, all serum samples were performed with and without previous absorption with Ascaris suum antigens ${ }^{4,31}$. Briefly, NC strips of $1 \times 1 \mathrm{~cm}$ were dotted on marked round areas with $2 \mu \mathrm{l}$ of TES antigens $(0.01 \mu \mathrm{g} / \mathrm{mL})$ diluted in bicarbonate buffer, $\mathrm{pH} 9.6$, containing $1 \%$ of ovalbumin. After drying, the strips were washed twice with PBS- $0.1 \%$ Tween 20 (PBS-T) and blocked with $5 \%$ non-fat milk in PBS/T at $4{ }^{\circ} \mathrm{C}$ overnight. All sera were tested at 1:200 dilutions in a volume of $13 \mu \mathrm{L}$, at room temperature for 40 min, and in humid chamber. Goat anti-human IgG-peroxidase conjugate (Sigma-Aldrich, US), 1:1000 dilution was added and incubated for 30 min and the reaction was developed for five min in a DAB substrate solution $(0.5 \mathrm{mg} / \mathrm{mL} \mathrm{3,3}$ '-diaminobenzidine tetrahydrochloride in PBS, $0.01 \%$ hydrogen peroxide). The reaction was stopped by washing it with tap water and the positive reaction was determined by visualization of defined brown dots on the round areas from strips. Additionally, all positive sera were serially two-fold diluted to determine the antibody concentration by titration. Among each step, strips were washed three times with PBS-T.

Hematological examination included total erythrocyte and leukocyte count, and leukocyte differential formula. Total erythrocyte and total leukocyte count was obtained by direct microscopic observation in a Neubauer chamber; leukocyte differential formula was obtained by stained-blood smear with Wright-Giemsa stain. Eosinophilia was defined as absolute eosinophils count more that 500 cells/ $\mu \mathrm{L}$ and eosinophils count was scored as: normal $(<6 \%)$, mild $(6-10 \%)$, moderate $(11-15 \%)$ or severe $(>15 \%)$ eosinophilia ${ }^{36}$.

Parasitological examination was realized by direct microscopic observation in fecal smears and by rapid sedimentation technique.

A database was constructed in an Excel spreadsheet for tabulation of the results and statistical analysis was carried out using the software Epi-Info 6.0. Chi-square test and Student-t test for paired samples were mainly used. The $p$ value considered as significant was $<0.05$.

\section{RESULTS}

From 256 tested serum samples (146 men and 110 women) $53.1 \%$ (136/256) were positive by dot-ELISA test without previous absorption with $A$. suum antigens. However, when all positive serum samples were retested with previous absorption with this antigen extract, the value of positivity decreased to $44.92 \%$ (115/256), confirming the possibility of cross-reactions with other helminth infections. The negative serum samples were always negative, before and after the absorption procedure.

From subjects with positive serology, $71.3 \%$ were male and $28.7 \%$ were female, $47.83 \%(55 / 115)$ had titers of $200,34.78 \%(40 / 115)$ titers of $400,11.03 \%(14 / 115)$ titers of 800 , and $5.22 \%$ (6/115) titers of 1600 . Association between sex and the serological test showed a significantly higher proportion of positivity in male subjects (Chi-square $=17.36$; $p<0.0001$ ). Age did not show significant differences between seropositive subjects (data not shown).

Ownership of dogs or/and cats showed a significant association (Chisquare $=28.30 ; p<0.0001$ ) with positivity to anti-Toxocara antibodies . Furthermore, the presence of pets inside the houses was significantly associated with seropositivity (Chi-square $=38.61 ; p<0.0001$ ). The use of public places by people showed a significant association with seropositivity to dot-ELISA test (Chi-square $=7.61 ; p=0.0058$ ) as well as previous history of pica or geophagia (Chi-square $=17.30$; $p<0.0001$ ) (Table 1).

The more frequent clinical findings in subjects with positive serology were respiratory signs $(46.96 \%)$, abdominal pain $(41.74 \%)$, hepatic compromise (31.30\%), cutaneous signs (18.26\%), ocular signs $(13.91 \%)$, and neurological symptoms $(1.74 \%)$. Presence of signs/symptoms were statistically associated (Chi-square $=4.82 ; p=0.0282)$ to positive serology (Table 2).

Association between eosinophils count and positive serology was statistically significant (Chi-square $=55.66 ; p<0.0001)$. From 115 subjects with positive serology, $26.96 \%$ had mild eosinophilia; $24.35 \%$ had moderate eosinophilia, and $4.35 \%$ had severe eosinophilia. In subjects with negative serology, $7.09 \%$ had mild eosinophilia and $4.96 \%$ had moderate eosinophilia.

Parasitological analysis revealed that $90.23 \%$ (231/256) of the total studied subjects were parasitized. From subjects with positive serology, 92.17\% (106/115) had at least one intestinal parasite, and the pathogen protozoan and coccidian parasites were as follows: Blastocystis hominis $68.38 \%$, Giardia lamblia $28.68 \%$, Entamoeba histolytica/E. dispar $13.24 \%$, Cyclospora cayetanensis $4.41 \%$, and Cryptosporidium sp. 


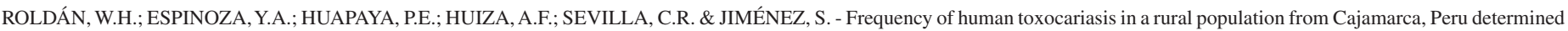
by DOT-ELISA test. Rev. Inst. Med. trop. S. Paulo, 51(2): 67-71, 2009.

Table 1

Risk factors related to toxocariasis serology in subjects from Cauday district, Peru, 2005

\begin{tabular}{|c|c|c|c|c|c|c|}
\hline \multirow{3}{*}{ Risk factors } & & \multicolumn{5}{|c|}{ Anti-Toxocara antibodies } \\
\hline & & \multicolumn{2}{|c|}{ Positive } & \multicolumn{2}{|c|}{ Negative } & \multirow{2}{*}{$p$ value* } \\
\hline & & $\mathbf{n}$ & $\%$ & $\mathbf{n}$ & $\%$ & \\
\hline \multirow{2}{*}{ Ownership of dogs/cats } & Yes & 109 & 94.8 & 96 & 68.1 & \multirow{2}{*}{0.0000} \\
\hline & No & 6 & 5.2 & 45 & 31.9 & \\
\hline \multirow{2}{*}{$\begin{array}{l}\text { Presence of pets within } \\
\text { the home }\end{array}$} & Yes & 108 & 93.9 & 85 & 60.3 & \multirow{2}{*}{0.0000} \\
\hline & No & 7 & 6.1 & 56 & 39.7 & \\
\hline \multirow{2}{*}{ Use of public places } & Yes & 115 & 100.0 & 132 & 93.6 & \multirow{2}{*}{0.0058} \\
\hline & No & 0 & 0 & 9 & 6.4 & \\
\hline \multirow{2}{*}{$\begin{array}{l}\text { History of pica or } \\
\text { geophagia }\end{array}$} & Yes & 92 & 80.0 & 78 & 55.3 & \multirow{2}{*}{0.0000} \\
\hline & No & 23 & 20.0 & 63 & 44.7 & \\
\hline
\end{tabular}

$* p \leq 0.05=$ significant value.

Table 2

Distribution of signs and symptoms as related to serology for toxocariasis in subjects from Cauday district, Peru, 2005

\begin{tabular}{lccccc}
\hline \multirow{2}{*}{ Signs and symptoms* } & \multicolumn{2}{c}{ Dot-ELISA (+) } & \multicolumn{2}{c}{ Dot-ELISA (-) } & \\
& $\mathrm{n}$ & $\mathbf{\%}$ & $\mathrm{n}$ & $\boldsymbol{\%}$ & \\
\hline Asymptomatic & 27 & 23.48 & 51 & 36.17 & $\mathbf{0 . 0 2 8 2}$ \\
Respiratory & 54 & 46.96 & 44 & 31.20 & $\mathbf{0 . 0 0 9 9}$ \\
Hepatic & 36 & 31.30 & 19 & 13.48 & $\mathbf{0 . 0 0 0 1}$ \\
Ocular & 16 & 13.91 & 10 & 7.09 & 0.0723 \\
Neurological & 2 & 1.74 & 1 & 0.71 & 0.6364 \\
Cutaneous & 21 & 18.26 & 23 & 16.31 & 0.6810 \\
Abdominal pain & 48 & 41.74 & 51 & 36.17 & 0.3628 \\
\hline
\end{tabular}

* Some subjects had more than one sign/symptom; ** $p \leq 0.05=$ significant value.

$1.47 \%$ and the helminthic parasites: Hymenolepis nana $20.0 \%$, Ascaris lumbricoides $15.65 \%$, Enterobius vermicularis $0.87 \%$, Strongyloides stercoralis $0.87 \%$, Taenia sp. $0.87 \%$, and Trichuris trichiura $0.87 \%$.

Because of the high percentage of subjects infected with helminth parasites, the frequency of positivity in the dot-ELISA apparently was higher when it was done without serum absorption with $A$. suum antigens. Nevertheless, with previous absorption of each serum sample, the rates of cross-reactions decreased over 50\%, especially in parasitized subjects with $A$. lumbricoides and $H$. nana, although statistical analysis revealed that these results were not significant $(\mathrm{t}=2.23 ; p=0.0675)$ (Table 3$)$.

\section{DISCUSSION}

In this research, a high percentage of anti-Toxocara antibodies frequency $(44.92 \%)$ was observed in this rural population using a dotELISA test as a serodiagnostic technique.

The frequency observed in this study is comparable with the one observed in Bogotá by AGUDELO et al. $(47.5 \%)^{1}$, but is lower than the
Table 3

Effect of serum absorption with Ascaris suum antigens with regard to the frequency of seropositivity in parasitized subjects determined by dot-ELISA test

Effect of serum absorption in the seropositivity $* *$

Intestinal parasites*

Before absorption After absorption

$$
(\mathrm{n}=136) \quad(\mathrm{n}=115)
$$

\begin{tabular}{lcccc} 
& $\mathrm{n}$ & $\%$ & $\mathrm{n}$ & $\%$ \\
\hline Ascaris lumbricoides $(\mathrm{n}=38)$ & 32 & 23.53 & 18 & 15.65 \\
Enterobius vermicularis $(\mathrm{n}=4)$ & 3 & 2.21 & 1 & 0.87 \\
Fasciola hepatica $(\mathrm{n}=3)$ & 1 & 0.74 & 0 & 0 \\
Hymenolepis nana $(\mathrm{n}=48)$ & 44 & 32.35 & 23 & 20.00 \\
Strongyloides stercoralis $(\mathrm{n}=7)$ & 5 & 3.68 & 1 & 0.87 \\
Taenia sp. $(\mathrm{n}=3)$ & 2 & 1.47 & 1 & 0.87 \\
Trichuris trichiura $(\mathrm{n}=6)$ & 4 & 2.94 & 1 & 0.87 \\
\hline
\end{tabular}

*Determined by parasitological examination in 256 subjects; ** Values and percentages vary according to frequency of seropositivity.

percentages observed in Caracas by FELIX-PIFANO et al. $(66.6 \%)^{14}$ or in Santa Lucia by THOMPSON et al. $(86 \%)^{35}$. The high association between male subjects and positive serology indicates that they might be at more risk for toxocariasis, probably because of the closer contact with soil, since they are farmers and ranchers.

High prevalence for Toxocara serology may result from various factors, the most important of which concerns living in conditions associated with rural and field infrastructure. Several studies have shown a higher frequency of Toxocara infection in male subjects, which may be due to differences in the behaviors within the home, the community, and work resulting in increased exposure to the eggs of Toxocara sp. ${ }^{17,21}$.

The ownership of dogs or/and cats were significantly associated with anti-Toxocara antibodies seropositivity as well as the presence of dogs or/ and cats within the house. CHIEFFI et al. ${ }^{8}$ and WOLFE et al $^{37}{ }^{37}$, reported a higher frequency of infection in individuals who were in contact with dogs. Ownership of dogs is very common in families living in the field, as they use the dogs to assist them with cattle, being considered very good work partners.

The use of public places by people is other important risk factor associated to human toxocariasis, since canine feces are very frequent in public places and playgrounds in other countries ${ }^{11,25,29,33}$. Although limited studies about soil contamination with Toxocara eggs in Peru have revealed a frequency ranging from $30 \%$ to $80 \%{ }^{6,21}$ this risk factor was significantly associated to Toxocara infection. It is possible that infection occurring in this population might have been brought about by accidental ingestion of Toxocara eggs contaminating soil of public places within the district.

The highly significant association between signs/symptoms and positive serology indicates us more evidence of Toxocara infection in this rural population. Hepatic and respiratory involvements were frequently found in these patients with a significant association with the seropositivity. Although $43.38 \%$ of the subjects with positive 
ROLDÁN, W.H.; ESPINOZA, Y.A.; HUAPAYA, P.E.; HUIZA, A.F.; SEVILLA, C.R. \& JIMÉNEZ, S. - Frequency of human toxocariasis in a rural population from Cajamarca, Peru determined by DOT-ELISA test. Rev. Inst. Med. trop. S. Paulo, 51(2): 67-71, 2009

serology had alterations in eosinophils count, only $3.67 \%$ had severe eosinophilia. Interestingly, when we analyzed these data with regard to signs/symptoms, they were not statistically associated (data not shown). Besides the presence of other parasites, these data can indicate that the studied population could be presenting atypical forms of toxocariasis (i.e. covert toxocariasis or incomplete VLM), due to the unspecific clinical picture and low frequency of eosinophilia ${ }^{11,24,34}$. These forms of human toxocariasis are different from the classical VLM, and are most frequent in people, as reported by different investigators around the world $11,16,18,24,27$.

In agreement with the study of KWON et al. ${ }^{20}$, we observed that $77.63 \%$ of total subjects with eosinophilia had positive serology by ELISA test. Some of the subjects with eosinophilia and negative serology also presented symptoms suggestive of toxocariasis. This may be due to recent Toxocara infection, other helminth parasites (very frequent in this population) or another unknown causes once peripheral eosinophilia is not always specific for toxocariasis and it may be associated with other helminth infections $\mathrm{s}^{24,27,32}$. Furthermore, intestinal parasite infections were detected in a high percentage of subjects (90.23\%), with a significant frequency of helminths $(70.7 \%)$ (data not shown).

In agreement with other investigators, the dot-ELISA test was made after absorption of serum samples with A. suum antigens in order to increment the specificity. Many authors refer that the main cause of crossreactions in serological tests for immunodiagnostics of toxocariasis are the presence of other helminth infections, while protozoa and coccidia are less related ${ }^{4,15,23,26}$. In our study, we observed false positive reactions in sera from parasitized subjects. When all serum samples were retested with previous serum absorption with $A$. suum antigens, cross-reactions decreased over $50 \%$ in parasitized subjects with $A$. lumbricoides, and in subjects with $H$. nana. It is known that there are antigenic similarities among Ascaris species, but it is very interesting to note that the A. suum antigens may help us to decrease the cross-reactions in cases of patients with $H$. nana, taking in consideration that this parasite belongs to other Phylum. Although statistically no significant $(\mathrm{t}=2.23 ; p=0.068)$, this serum absorption procedure could eliminate totally or partially the crossreactions in some cases, these findings demonstrates that the previous serum absorption with $A$. suum antigens would improve the dot-ELISA performance, as mentioned by others ${ }^{4,26,31}$. On the other hand, we could not exclude the possibility of mixed infections between Toxocara sp. and other helminthes, since the presence of risk factors and clinical findings for Toxocara infection found in this study were highly significant.

The high frequency of helminth infections observed in our study suggests that other risk factors described for Toxocara infection, such as poor hygiene habits and sanitary behaviors, must have contributed to $i^{1} t^{1,17,25,35}$. Protozoan and helminth infections have been found in similar population from other South America cities ${ }^{5,7,10,23}$. We also note that the presence of mixed infections between Toxocara and other helminths can contribute to increase the frequency of positivity using conventional serological tests, as the one of this study.

The high rate for toxocariasis frequency could be the result of several factors, but doubtless the most important is the social characteristics of Cauday district, a town with an extended area without paved streets and with deficient daily cleaning and a high percentage of people with unsatisfied basic needs and with dogs living at home.
Serological and epidemiological characteristics for Toxocara infection were observed in the present study. Future studies about soil contamination should be done to better assess the magnitude of this serious health problem, and community education programs should be developed to promote the social concept of a responsible pet ownership.

\section{RESUMO}

\section{Freqüiência de toxocaríase humana numa população rural de Cajamarca, Peru, mediante o uso do teste DOT-ELISA}

O propósito do presente estudo foi estimar a freqüência da toxocaríase no distrito de Cauday, Cajamarca, Peru, usando o dot-ELISA teste. Entre junho e outubro de 2005, um total de 256 pessoas foram avaliadas. Coletaram-se amostras de sangue para o teste de dot-ELISA e para o exame hematológico e amostras de fezes para exame parasitológico. A frequiência geral de anticorpos anti-Toxocara observada foi de $44,92 \%$, com maior proporção significativa de positividade em pessoas do sexo masculino. Das pessoas com sorologia positiva, 45,6\% apresentavam sintomas respiratórios, 40,44\% dores abdominais, 32,35\% moléstias hepáticas, $14,7 \%$ sinais cutâneos, $13,23 \%$ manifestações oculares, $43,38 \%$ eosinofilia e todos estes fatores foram estatisticamente associados à sorologia. Entre as pessoas avaliadas 90,23\% estavam parasitadas e $92,17 \%$ das pessoas com sorologia positiva tinham algum parasito intestinal, sendo os mais freqüentes: Blastocystis hominis (68,38\%), Giardia lamblia (28,68\%), Hymenolepis nana $(20,0 \%)$, Ascaris lumbricoides (15,65\%), Entamoeba histolytica/E. dispar (13,24\%), Cyclospora cayetanensis (4,41\%), Cryptosporidium sp. (1,47\%), Enterobius vermicularis $(0,87 \%)$, Strongyloides stercoralis $(0,87 \%)$, Taenia $\mathrm{sp} .(0,87 \%)$ e Trichuris trichiura $(0,87 \%)$. A taxa de falsos positivos no teste dot-ELISA foi melhorada pela absorção dos soros com antígenos de A. suum, com diminuição das reações cruzadas. Em conclusão, a toxocaríase humana é altamente freqüente nesta população e fatores de risco como ter um cão/ gato, presença dos animais dentro de casa e estória prévia de geofagia foram observados durante o presente estudo.

\section{REFERENCES}

1. AGUDElO, C.; VillareAL, E.; CÁCERES, E. et al. - Human and dogs Toxocara canis infection in a poor neighborhood in Bogotá. Mem. Inst. Oswaldo Cruz, 85: 75-78, 1990

2. ALDERETE, J.M.S.; JACOB, C.M.A.; PASTORINO, A.C. et al. - Prevalence of Toxocara infection in schoolchildren from the Butantã region, São Paulo, Brazil. Mem. Inst. Oswaldo Cruz, 98: 593-597, 2003.

3. ALONSO, J.M.; BOJANICH, M.V.I; CHAMORRO, M. \& GORODNER, J.O. - Toxocara frequency in children from a subtropical city in Argentina. Rev. Inst. Med. trop. S. Paulo, 42: 235-237, 2000.

4. CAMARGO, E.D.; NAKAMURA, P.M.; VAZ, A.J. et al. - Standardization of dot-ELISA for the serological diagnosis of toxocariasis and comparison of the assay with ELISA. Rev. Inst. Med. trop. S. Paulo, 34: 55-60, 1992.

5. CASAPÍA, M.; JOSEPH, S.A.; NÚÑEZ, C.; RAHME, E. \& GYORKOS, T.W. - Parasite risk factors for stunting in grade 5 students in a community of extreme poverty in Peru. Int. J. Parasit., 36: 741-747, 2006.

6. CHÁVEZ, A.; CASAS, E.; CAJAS, J. \& VELARDE, J. - Contaminación de parques públicos con huevos de Toxocara sp. en los distritos de la provincia constitucional del Callao y del cono sur de Lima metropolitana. Rev. Invest. Vet. Peru, 11: 52-57, 2000 . 
ROLDÁN, W.H.; ESPINOZA, Y.A.; HUAPAYA, P.E.; HUIZA, A.F.; SEVILLA, C.R. \& JIMÉNEZ, S. - Frequency of human toxocariasis in a rural population from Cajamarca, Peru determined by DOT-ELISA test. Rev. Inst. Med. trop. S. Paulo, 51(2): 67-71, 2009.

7. CHERO, J.C.; SAITO, M.; BUSTOS, J.A. et al. - Hymenolepis nana infection: symptoms and response to nitazoxanide in field conditions. Trans. roy. Soc. trop. Med. Hyg., 101: 203-205, 2007

8. CHIEFFI, P.P.; UEDA, M.; CAMARGO, E.D. et al. - Contato domiciliar e profissional com cães como fatores de risco para infecção humana por larvas de Toxocara. Rev. Inst. Med. trop. S. Paulo, 30: 379-382, 1988.

9. CHIEFFI, P.P.; UEDA, M.; CAMARGO, E.D. et al. - Visceral larva migrans: a seroepidemiological survey in five municipalities of São Paulo State, Brazil. Rev. Inst. Med. trop. S. Paulo, 32: 204-210, 1990.

10. CLEARY, J.D.; GRAHAM, D.; LUSHBAUGH, W.B.; NOLAN, R.L. \& CHAPMAN, S.W. - Single low-dose mebendazole administered quarterly for ascaris treatment. Amer. J. med. Sci., 333: 340-345, 2007.

11. DESPOMMIER, D. - Toxocariasis: clinical aspects, epidemiology, medical ecology, and molecular aspects. Clin. Microb. Rev., 16: 265-272, 2003.

12. ESPINOZA, Y.; HUAPAYA, P.; SEVILLA, C. \& HUIZA, A. - Toxocariosis humana: seroprevalencia en la población de Lima mediante la técnica de ELISA. An. Fac. Med. (Lima), 64: 228-232, 2003.

13. ESPINOZA, Y.; HUAPAYA, P.; AYLLÓN, C. et al. - Toxocariosis humana en pacientes con lesión ocular. An. Fac. Med. (Lima), 64: 247-251, 2003.

14. FELIX-PIFANO, C.F.; ORIHUELA, A.R. \& DELGADO, O. - La toxocariasis humana en Venezuela, especialmente en el valle de Caracas. Gac. méd. Caracas, 96: 31-41, 1989

15. GARCÍA, H.H.; CANCRINI, G.; BARTALESI, F. et al. - . Evaluation of immunodiagnostics for toxocarosis in experimental porcine cysticercosis. Trop. Med. Int. HIth, 12: 107$110,2007$.

16. GLICKMAN, L.T. \& CYPESS, R.H. - Toxocara infection in animal hospital employees. Amer. J. publ. Hlth, 67: 1193-1195, 1977.

17. HABLUETZEL, A.; TRALDI, G.; RUGGIERI, S. et al. - An estimation of Toxocara canis prevalence in dogs and environmental egg contamination as risk of human infection in the Marche region of Italy. Vet. Parasit., 113: 243-252, 2003.

18. HIRATA, T.; YAMASAKI, K.; LI, Y.G.; MAJIMA, Y. \& TSUJI, M - Demonstration of hepatic granuloma due to visceral larva migrans by ultrasonography. J. clin. Ultrasound, 18: 429-433, 1990 .

19. JACQUIER, P.; GOTTSTEIN, B.; STINGELIN, Y. \& ECKERT, J. - Immunodiagnosis of toxocariasis in humans: evaluation of a new enzyme-linked immunosorbent assay kit. J. clin. Microbiol., 29: 1831-1835, 1991.

20. KWON, N.H.; OH, M.J.; LEE, B.J. \& CHOI, D.C. - The prevalence and diagnostic value of toxocariasis in unknown eosinophilia. Ann. Hemat., 85: 233-238, 2006.

21. LESCANO, S.A.Z.; CHIEFFI, P.P.; PERES, B. et al. - Soil contamination and human infection by Toxocara sp. in the urban area of Lima, Peru. Mem. Inst. Oswaldo Cruz, 93: 733-734, 1998.
22. LYNCH, N.R.; EDDY, K.; HODGEN, A.N.; LOPEZ, R.I. \& TURNER, K.J. - Frequency of Toxocara canis infection in tropical Venezuela. Trans. roy. Soc. trop. Med. Hyg., 82: $275-281,1988$.

23. LYNCH, N.R.; WILKES, L.K.; HODGEN, A.N. \& TURNER, K.J. - Specificity of Toxocara ELISA in tropical populations. Paras. Immunol., 10: 323-337, 1988.

24. MAGNAVAL, J.F.; GLICKMAN, L.T.; DORCHIES, P. \& MORASSIN, B. - Highlights of human toxocariasis. Korean J. Parasit., 39: 1-11, 2001.

25. MIZGAJSKA, H. - Eggs of Toxocara spp. in the environment and their public health implications. J. Helminth., 75: 147-151, 2001

26. NUNES, C.M.; TUNDISI, R.N.; GARCIA, J.F. et al. - Cross-reactions between Toxocara canis and Ascaris suum in the diagnosis of visceral larva migrans by Western blotting technique. Rev. Inst. Med. trop. S. Paulo, 39: 253-256, 1997.

27. PAWLOWSKI, Z. - Toxocariasis in humans: clinical expression and treatment dilemma J. Helminth., 75: 299-305, 2001.

28. PORTÚS, M.; RIERA, C. \& PRATS, G. - A serological survey of toxocariasis in patient and healthy donors in Barcelona (Spain). Europ. J. Epidem., 5: 224-227, 1989.

29. QUEIROZ, M.L.; SIMONSEN, M.; PASCHOALOTTI, M.A. \& CHIEFFI, P.P. Frequency of soil contamination by Toxocara canis eggs in the south region of São Paulo municipality (SP, Brazil) in a 18 month period. Rev. Inst. Med. trop. S. Paulo, 48: 317-319, 2006.

30. RADMAN, N.E.; ARCHELLI, S.M.; FONROUGE, R.D.; GUARDIS, M. \& LINZITTO O.R. - Human toxocariosis. Its seroprevalencein the city of La Plata. Mem. Inst. Oswaldo Cruz, 95: 281-285, 2000

31. ROLDÁN, W.; CORNEJO, W. \& ESPINOZA, Y. - Evaluation of the dot-ELISA in comparison with standard ELISA for the immunodiagnosis of human toxocariasis. Mem. Inst. Oswaldo Cruz, 101: 71-74, 2006.

32. ROTHENBERG, M.E. - Eosinophilia. New Engl. J. Med., 338: 1592-1600, 1998

33. SHIELDS, J.A. - Ocular toxocariasis. A review. Surv. Ophthalmol., 28: 361-381, 1984

34. TAYLOR, M.R.; KEANE, C.T.; O’CONNOR, P.; MULVIHILL, E. \& HOLLAND, C. The expanded spectrum of toxocaral disease. Lancet, 1: 692-694, 1988.

35. THOMPSON, D.E.; BUNDY, D.A.P.; COOPER, E.S. \& SCHANTZ, P.M. Epidemiological characteristics of Toxocara canis zoonotic infection of children in a Caribbean community. Bull. Wld Hlth Org., 64: 283-290, 1986

36. WILLIAMS, W.J.; BEUTLER, E.; ERSLEV, A.J. \& LICHTMAN, A.M. - Hematology. 4 ed. New York, Mc Graw-Hill, 1991. p. 1832-1833.

37. WOLFE, A. \& WRIGHT, I.P. - Human toxocariasis and direct contact with dogs. Vet. Rec., 152: 419-422, 2003.

Received: 7 May 2008

Accepted: 9 December 2008 